\title{
Direct and Residual Effects of Different Levels of Chicken Manure Fertilization on the Growth and Biomass Production of Brachiaria ruziziensis (Poaceae) at the Bolting in West Cameroon
}

\author{
Gilles Jiope Azangue ${ }^{1 *}$, Fernand Tendonkeng2, François Victor Nguetsop1, David Fokom Wauffo², \\ Etienne Tedonkeng Pamo² \\ ${ }^{1}$ Department of Plant Biology, Faculty of Science, University of Dschang, Dschang, Cameroon \\ ${ }^{2}$ Department of Animal Productions, Faculty of Agronomy and Agricultural Sciences, University of Dschang, Dschang, Cameroon \\ Email: *azangilles@yahoo.fr
}

How to cite this paper: Azangue, G.J., Tendonkeng, F., Nguetsop, F.V., Wauffo, D.F. and Pamo, E.T. (2019) Direct and Residual Effects of Different Levels of Chicken Manure Fertilization on the Growth and Biomass Production of Brachiaria ruziziensis (Poaceae) at the Bolting in West Cameroon. Agricultural Sciences, 10, 1113-1123. https://doi.org/10.4236/as.2019.108084

Received: July 13, 2019

Accepted: August 27, 2019

Published: August 30, 2019

Copyright $\odot 2019$ by author(s) and Scientific Research Publishing Inc. This work is licensed under the Creative Commons Attribution International License (CC BY 4.0).

http://creativecommons.org/licenses/by/4.0/

\begin{abstract}
The direct and residual effects of different levels of chicken manure fertilization on the growth and biomass production of B. ruziziensis at the bolting were studied in West Cameroon. The objective of this study was to evaluate the effects of different levels of chicken manure fertilization on the growth and biomass production of Brachiaria ruziziensis at the bolting. A factorial device comparing five doses of nitrogen into chicken manure $(0,25,50,75$ and $100 \mathrm{~kg} \mathrm{~N} / \mathrm{ha}$ ) on plot of $6 \mathrm{~m}^{2}(3 \times 2 \mathrm{~m})$ in four replicates, (i.e. a total of 20 experimental plots) was used. Chicken manure was spread one month after planting pieces of stump during the first year. In the second year, no fertilization was brought up. 40 plants were harvested by treatment for heights and diameters measurements. The evaluation of stems biomass, leaves and whole plants was done on each plot based on the level of fertilization. The results obtained showed that chicken manure fertilization had a positive effect on the growth and biomass production of the $B$. ruziziensis on the direct and residual effect of fertilization. Thus, the height, diameters and biomass of whole plants in the fertilized plots were significantly larger than in the control plots. The mineralization of the organic matter contained in the chicken manure with doses of $100 \mathrm{~kg} \mathrm{~N} / \mathrm{ha}$ was done on the direct and residual effect in order to assure a maximal plant growth. The level of $\mathrm{T}_{4}$ fertilization (corresponding to the dose of $100 \mathrm{~kg} \mathrm{~N} / \mathrm{ha}$ ) gave the best results. Referring to the result obtained, the level of $T_{4}$ fertilization corresponding to $100 \mathrm{~kg} \mathrm{~N} / \mathrm{ha}$ would be
\end{abstract}


suitable for an optimal B. ruziziensis growth in order to avoid providing the soil with mineral fertilizer.

\section{Keywords}

Brachiaria ruziziensis, Chicken Manure, Height, Diameter, Biomass

\section{Introduction}

The necessity to feed an ever-increasing population in developing countries is pushing farmers to exploit marginal land considered unsuitable for agriculture [1], to expand arable land at the detriment of pastoral land, resulting in conflicts over the use of rural space between farmers and herders [2] [3]. This situation leads to the narrowing of natural rangelands [3] [4], and to their displacement towards marginal areas [5] which are already overexploited. Natural grasslands, which have been used extensively to date, are becoming depleted and losing their capacity to raise livestock [6]. It is, therefore, necessary to develop a sedentary type of livestock farming which, being based on active land work, ensures its conservation and increases its productivity [6]. This type of livestock farming allows for intensive and sustainable use of land resources and facilitates livestock management. If the aim is to move from nomadic to sedentary livestock farming, then there is a need to increase the supply of fodder within the sedentary area [6]. Fodder cultivation can be an alternative in tropical countries. It would thus ensure availability both in favorable periods (rainy season) and in unfavorable periods (dry season) [7] [8]. In this case, production systems will no longer have the only aim of producing milk and meat, but will also make it possible to produce good quality fodder using cultivation techniques accessible to farmers [9]. Among the many forage species introduced into Cameroon, there is the Brachiaria ruziziensis. This perennial gramineae has the advantages of better adaptation in different regions, good nutritional value and produces a good appetite to the animals [3] [4]. It is proposed for profitable use not only in improving natural pastures, but also as green or conserved forage [3] [10]. The cultivation of $B$. ruziziensis and especially the intensification of its use can thus constitute a palliative to the shrinking of natural rangelands [11]. It would improve animal rations throughout the year. Plants of genus Brachiaria are able to extract the few nutrients left in poor soils. As a result, their intensive use as fodder, without the use of fertilizer (fertilizer or manure) as compensation, may lead to the depletion of soils that will become uncultivated [12]. Considering the high cost of mineral fertilizers and their harmful role in soil ecology, the use of chicken manure has enormous potential for managing soil fertility and improving crop growth and yields [13]. It is with this in mind that this study aims to evaluate the effect of chicken manure on the growth and biomass production of B. ruziziensis. The aim is to determine the optimal level of certain nutrients such 
as nitrogen in chicken manure and its immediate or distant effects on the plant's growth and biomass production over time.

\section{Materials and Methods}

\subsection{Study Area}

The study was conducted at the Research and Experimental Farm (REF) of the University of Dschang between April 2015 and December 2016. REF is located in the West Cameroon region, in the Menoua division, Dschang subdivision, at $05^{\circ} 20^{\prime}$ north latitude and $10^{\circ} 03^{\prime}$ east longitude [14]. The climate of the entire territory is a Cameroonian equatorial climate with mountainous features determined by the altitude, the average altitude of which is $1400 \mathrm{~m}$. It is characterized by a rainy season from mid-March to mid-November and a dry season from mid-November to mid-March [15] [16]. The average temperature of the hottest month (February) is $25^{\circ} \mathrm{C}$ and the average temperature of the coolest month is $10^{\circ} \mathrm{C}$ and is in July or August. The annual sunshine is 1800 hours, the relative humidity varying between $40 \%$ and $97 \%$. Rainfall varies between 1500 and 2000 mm per year [11] [17].

\subsection{Experimental Device}

A factorial device $(5 \times 3)$ comparing five doses of nitrogen in the form of chicken manure $(0,25,50,75$ and $100 \mathrm{~kg} \mathrm{~N} / \mathrm{ha})$ on $6 \mathrm{~m}^{2}(3 \times 2 \mathrm{~m})$ plots in four replicates, for a total of 20 experimental plots was used.

\subsection{Origin and Chemical Composition of the Fertilizer}

The organic fertilizer used in this study is chicken manure. It was obtained from a breeding at a producer in the division of Menoua (Dschang). Its chemical composition was analyzed at the Laboratory of Soil Analysis and Environmental Chemistry of the University of Dschang in order to determine the quantities to be applied. The results of the analysis of the chemical composition of chicken manure were presented in Table 1.

\subsection{Soil Preparation, Plant Placement and Fertilization}

Soil samples were collected at the test site in a depth range of $0-20 \mathrm{~cm}$ before soil preparation and stump splinters were placed. The soil chemical analysis was carried out at the Laboratory for Soil Analysis and Environmental Chemistry of the University of Dschang using the method described by Pauwels et al. [18]. The results obtained showed that the average textural class of this soil is silty. This soil is slightly acidic with an average $\mathrm{pH}$ of 5.5, which excludes the risk of toxicity due to excess aluminum and manganese. Total nitrogen levels are low $(0.6 \mathrm{~g} / \mathrm{kg}$ soil). For most Cameroonian soils, levels of $1 \mathrm{~g} / \mathrm{kg}$ already allow a crop cycle in traditional agriculture, but for intensive cultivation, these levels must be increased to $2 \mathrm{~g} / \mathrm{kg}$. It is, therefore, necessary to provide a nitrogen supplement. The organic matter rate (with a $\mathrm{C} / \mathrm{N}$ ratio $=11.66$ ) is within the ideal range 
Table 1. Chemical composition of chicken manure.

\begin{tabular}{ccccccc}
\hline & N & K & P & Na & Ca & Mg \\
\hline Content $(\mathrm{mg} / \mathrm{kg})$ & 2600 & 20,438 & 809 & 1015 & 6960 & 73,046 \\
\hline
\end{tabular}

(8\% - 12\%) reflecting good organic matter mineralization [19]. This gives this soil a greater retention capacity that can allow it to withstand massive fertilization. As for exchangeable bases, the soil is poorly supplied with magnesium, potassium, calcium and phosphorus. The absorbent complex of this soil has a high cation exchange capacity $(7.84 \mathrm{cmol} / \mathrm{kg}$ soil) due to the high organic matter. These characteristics make it possible to consider without fear fertilization with high doses of fertilizer. Indeed, the fertility level of soil is optimal when the physico-chemical and climatic conditions specific to a given cultivar are provided. In the case of $B$. ruziziensis, which requires highly fertile soil [10], these conditions are acceptable in the West Cameroon highlands and subsequent inputs may positively modify this environment in order to improve its cultivation.

The preparation of the $6 \mathrm{~m}^{2}(3 \times 2 \mathrm{~m})$ seedling blocks was done manually using a decameter and stakes to delimit the blocks and corridors; machetes, hoes and pickaxes were used to develop the blocks and loosen the soil. Stump chips containing several B. ruziziensis plants were collected from the REF course, then dressed (by reducing leaf and root size) with a machete and transplanted to each plot $4 \mathrm{~cm}$ deep, at a spacing of $20 \mathrm{~cm} \times 15 \mathrm{~cm}$ respectively between and on the line.

Fertilization levels at chicken manure have been defined in terms of the amount of nitrogen contained in chicken manure not only because nitrogen is the most deficient nutrient in agricultural production systems through its role in the synthesis of living matter [20], but also because it is a yield and sometimes quality factor that increases the protein content in plants [21].

Thus, five nitrogen doses were defined $(0,25,50,75$ and $100 \mathrm{~kg}$ nitrogen per hectare) for the cultivation of B. ruziziensis. Each dose was assigned a specific quantity of chicken manure as summarized in Table 2 . In the second year (January 2016), regularization mowing was carried out at $5 \mathrm{~cm}$ above the ground, and no fertilization was carried out after the regularization mowing. The maintenance of the plots consisted each month of manual weeding of the weeds.

\subsection{Data Collection}

\subsubsection{Growth Assessment}

To assess growth, ten (10) plants were randomly collected from each replicate, for a total of 40 plants per treatment to assess measurements (height and diameter). Plant heights (from the mowing point to the end of the longest leaf) were measured using a tape measure per centimeter and diameters were measured (before the first internode) using an electronic caliper graduated to the millimeter. 
Table 2. Quantities of organic fertilizer applied.

\begin{tabular}{ccc}
\hline Fertilization levels & $\begin{array}{c}\text { Quantity of manure applied } \\
(\mathrm{kg} / \mathrm{plot})\end{array}$ & $\begin{array}{c}\text { Equivalent nitrogen dose } \\
(\mathrm{kg} \mathrm{N} / \mathrm{ha})\end{array}$ \\
\hline $\mathrm{T}_{0}$ & 0 & 0 \\
$\mathrm{~T}_{1}$ & 5.77 & 25 \\
$\mathrm{~T}_{2}$ & 11.53 & 50 \\
$\mathrm{~T}_{3}$ & 17.30 & 75 \\
$\mathrm{~T}_{4}$ & 23.07 & 100 \\
\hline
\end{tabular}

\subsubsection{Biomass Assessment}

In order to evaluate the biomasses for each level of fertilization, 20 blocks (four repetitions per treatment) were mowed using a cutting table and knives. During mowing and to avoid border effects, B. ruziziensis was mowed $5 \mathrm{~cm}$ above the ground on a useful surface of $2 \mathrm{~m}^{2}(2 \times 1 \mathrm{~m})$ in the centre of the block. The forage thus harvested was then weighed. A representative sample of $0.5 \mathrm{~kg}$ of $B$. ruziziensis was taken per fertilization level from each block. Each sample was then separated into leaves and stems which were cut and dried at $60^{\circ} \mathrm{C}$ in a ventilated Gallemkamp oven up to constant weight for dry matter determination and efficiency evaluation.

\subsubsection{Statistical Analysis}

The data on height, diameter and biomass produced were subjected to a multifactorial analysis of variance according to the General Linear Model (GLM) using the SPSS software version 20.0. When there were differences between the different treatments, the means were separated by the Duncan test at the $5 \%$ significance level [22].

\section{Results}

\subsection{Direct and Residual Effects of Different Levels of Chicken Manure Fertilization on the Height of Brachiaria ruziziensis during the Bolting}

The variations in the height of $B$. ruziziensis under the direct and residual effect of increasing levels of fertilization at the bolting are presented in Table 3 .

Table 3 shows that the plant heights of the plots fertilized at 25 and $50 \mathrm{~kg}$ $\mathrm{N} /$ ha obtained under the direct effect ( 157.47 and $160.42 \mathrm{~cm}$ respectively) were higher $(\mathrm{p}<0.05)$ than the plant heights obtained under the residual effect for the same doses (152.43 and $153.40 \mathrm{~cm}$ respectively).

In contrast, the plant heights of the plots fertilized at 75 and $100 \mathrm{~kg} \mathrm{~N} / \mathrm{ha}$ obtained under the residual effect of the fertilizer ( 198.80 and $197.88 \mathrm{~cm}$ respectively) were higher $(\mathrm{p}<0.05)$ than the plant heights obtained under the direct effect of the fertilizer ( 163.82 and $167.70 \mathrm{~cm}$ respectively). The plant heights of the fertilized plots were higher than those of the unfertilized plots under both the direct and residual effect of the fertilizer. 
Table 3. Direct and residual effects of different levels of fertilization with chicken manure on the height (in $\mathrm{cm}$ ) of B. ruziziensis during the bolting.

\begin{tabular}{ccccc}
\hline Fertilization levels & Direct effect & Residual effect & SEM & $\mathrm{p}$ \\
\hline $\mathrm{T}_{0}$ & $153.42^{\mathrm{a}}$ & $151.45^{\mathrm{a}}$ & 1.56 & 0.214 \\
$\mathrm{~T}_{1}$ & $157.47^{\mathrm{b}}$ & $152.42^{\mathrm{a}}$ & 1.93 & 0.0001 \\
$\mathrm{~T}_{2}$ & $160.42^{\mathrm{b}}$ & $153.40^{\mathrm{a}}$ & 1.95 & 0.0001 \\
$\mathrm{~T}_{3}$ & $163.82^{\mathrm{a}}$ & $198.80^{\mathrm{b}}$ & 2.41 & 0.0001 \\
$\mathrm{~T}_{4}$ & $167.70^{\mathrm{a}}$ & $197.88^{\mathrm{b}}$ & 1.79 & 0.0001 \\
\hline
\end{tabular}

a,b: averages with the same letters on the same line are not significant at the $5 \%$ threshold. SEM: standard error of means; $\mathrm{T}_{0}=$ control, $\mathrm{T}_{1}=25 \mathrm{~kg} \mathrm{~N} / \mathrm{ha}, \mathrm{T}_{2}=50 \mathrm{~kg} \mathrm{~N} / \mathrm{ha}, \mathrm{T}_{3}=75 \mathrm{~kg} \mathrm{~N} / \mathrm{ha}, \mathrm{T}_{4}=100 \mathrm{~kg} \mathrm{~N} / \mathrm{ha}$.

\subsection{Direct and Residual Effects of Different Levels of Chicken Manure Fertilization on the Diameter of Brachiaria ruziziensis during the Bolting}

The variation in the diameter of B. ruziziensis as a function of the different levels of fertilization under the direct and residual effect of the fertilizer is presented in Table 4.

Table 4 shows that the diameters of the plants obtained under the direct effect of fertilization were larger $(p<0.05)$ than those obtained under the residual effect of fertilizer. The plant diameters of the fertilized plots were larger than those of the control plots. Fertilization at a rate of $100 \mathrm{~kg} \mathrm{~N} / \mathrm{ha}$ allowed the largest diameters to be obtained under the direct and residual effect of the fertilizer.

\subsection{Direct and Residual Effects of Different Levels of Chicken Manure Fertilization on Biomass Production of $B$. ruziziensis during the Bolting}

The evolution of the biomass of leaves, stems and the whole plant of B. ruziziensis under the direct and residual effect of the different levels of fertilization at the bolting is presented in Table 5 .

Table 5 shows that the biomass of leaves and whole plants obtained under the residual effect of fertilization was higher $(p<0.05)$ than that obtained under the direct effect of fertilization. At the stem level, the biomasses obtained under the direct and residual effect of the fertilizer were comparable to each other. Fertilization resulted in higher biomass of leaves, stems and whole plants than the control plots. At the stem and whole plant level, fertilization at $100 \mathrm{~kg} \mathrm{~N} / \mathrm{ha}$ resulted in the highest biomasses under the direct and residual effect of the fertilizer.

\section{Discussion}

Fertilization with chicken manure has positively influenced the evolution of the height and diameter of $B$. ruziziensis plants under the direct and residual effect of the fertilizer. The heights and diameters of the plants in the fertilized plots 
Table 4. Direct and residual effects of different levels of fertilization with chicken manure on the diameter (in $\mathrm{mm}$ ) of B. ruziziensis during the bolting.

\begin{tabular}{ccccc}
\hline Fertilization levels & Direct effect & Residual effect & SEM & $p$ \\
\hline $\mathrm{T}_{0}$ & $3.60^{\mathrm{b}}$ & $2.48^{\mathrm{a}}$ & 0.05 & 0.0001 \\
$\mathrm{~T}_{1}$ & $4.03^{\mathrm{b}}$ & $2.78^{\mathrm{a}}$ & 0.06 & 0.0001 \\
$\mathrm{~T}_{2}$ & $4.10^{\mathrm{b}}$ & $2.85^{\mathrm{a}}$ & 0.08 & 0.0001 \\
$\mathrm{~T}_{3}$ & $4.00^{\mathrm{b}}$ & $2.93^{\mathrm{a}}$ & 0.06 & 0.0001 \\
$\mathrm{~T}_{4}$ & $4.08^{\mathrm{b}}$ & $2.95^{\mathrm{a}}$ & 0.03 & 0.0001 \\
\hline
\end{tabular}

a, b: averages with the same letters on the same line are not significant at the $5 \%$ threshold. $\mathrm{T}_{0}=$ control, $\mathrm{T}_{1}$ $=25 \mathrm{~kg} \mathrm{~N} / \mathrm{ha}, \mathrm{T}_{2}=50 \mathrm{~kg} \mathrm{~N} / \mathrm{ha}, \mathrm{T}_{3}=75 \mathrm{~kg} \mathrm{~N} / \mathrm{ha}, \mathrm{T}_{4}=100 \mathrm{~kg} \mathrm{~N} / \mathrm{ha}$.

Table 5. Direct and residual effects of different levels of chicken manure fertilization on biomass production (in t DM/ha) of leaves, stems and the whole plants of B. ruziziensis during the bolting.

\begin{tabular}{cccccc}
\hline & Fertilization levels & Direct effect & Residual effect & SEM & p \\
\hline \multirow{4}{*}{ Leaves } & $\mathrm{T}_{0}$ & $8.11^{\mathrm{a}}$ & $11.54^{\mathrm{b}}$ & 0.172 & 0.0001 \\
& $\mathrm{~T}_{1}$ & $8.65^{\mathrm{a}}$ & $15.41^{\mathrm{b}}$ & 0.199 & 0.0001 \\
& $\mathrm{~T}_{2}$ & $9.20^{\mathrm{a}}$ & $15.40^{\mathrm{b}}$ & 0.200 & 0.0001 \\
& $\mathrm{~T}_{3}$ & $8.69^{\mathrm{a}}$ & $18.23^{\mathrm{b}}$ & 0.101 & 0.0001 \\
& $\mathrm{~T}_{4}$ & $9.09^{\mathrm{a}}$ & $17.96^{\mathrm{b}}$ & 0.245 & 0.0001 \\
& $\mathrm{~T}_{0}$ & $10.13^{\mathrm{a}}$ & $10.77^{\mathrm{a}}$ & 0.233 & 0.270 \\
& $\mathrm{~T}_{1}$ & $11.72^{\mathrm{a}}$ & $10.89^{\mathrm{a}}$ & 0.263 & 0.174 \\
& $\mathrm{~T}_{2}$ & $13.17^{\mathrm{a}}$ & $11.37^{\mathrm{a}}$ & 0.179 & 0.005 \\
& $\mathrm{~T}_{3}$ & $14.42^{\mathrm{a}}$ & $14.84^{\mathrm{a}}$ & 0.196 & 0.333 \\
& $\mathrm{~T}_{4}$ & $15.03^{\mathrm{a}}$ & $15.48^{\mathrm{a}}$ & 0.253 & 0.461 \\
& $\mathrm{~T}_{0}$ & $18.22^{\mathrm{a}}$ & $22.27^{\mathrm{b}}$ & 0.191 & 0.0001 \\
& $\mathrm{~T}_{1}$ & $20.37^{\mathrm{a}}$ & $26.30^{\mathrm{b}}$ & 0.199 & 0.0001 \\
& $\mathrm{~T}_{2}$ & $22.37^{\mathrm{a}}$ & $26.77^{\mathrm{b}}$ & 0.206 & 0.0001 \\
& $\mathrm{~T}_{3}$ & $23.11^{\mathrm{a}}$ & $33.07^{\mathrm{b}}$ & 0.193 & 0.0001 \\
& $\mathrm{~T}_{4}$ & $24.12^{\mathrm{a}}$ & $33.44^{\mathrm{b}}$ & 0.300 & 0.0001 \\
\hline
\end{tabular}

a, b: averages with the same letters on the same line are not significant at the $5 \%$ threshold. $\mathrm{T}_{0}=$ control, $\mathrm{T}_{1}$ $=25 \mathrm{~kg} \mathrm{~N} / \mathrm{ha}, \mathrm{T}_{2}=50 \mathrm{~kg} \mathrm{~N} / \mathrm{ha}, \mathrm{T}_{3}=75 \mathrm{~kg} \mathrm{~N} / \mathrm{ha}, \mathrm{T}_{4}=100 \mathrm{~kg} \mathrm{~N} / \mathrm{ha}$.

were higher than those in the unfertilized plots. The differences observed between the heights of the plants in the fertilized plots and those in the unfertilized plots can be explained by the fact that the low nitrogen contents $(0.6 \mathrm{~g} / \mathrm{kg}$ soil $)$ contained in the soil of the unfertilized plots did not correspond to the quantity necessary for optimal growth of this plant. Thus, nitrogen inputs in the form of chicken manure made it possible to obtain significant differences in the plant diameters of the fertilized plots compared to those of the control plots. In addition, the results of studies conducted by Yerima et al. [13] showed that chicken 
manure significantly improves soil properties, making them more productive. This highlights the role of chicken manure in plant growth and development.

The heights and plant diameters of the plots fertilized at 75 and $100 \mathrm{~kg} \mathrm{~N} / \mathrm{ha}$ were higher than those obtained for the lower fertilization levels under the direct and residual effect of the fertilizer. Indeed, fertilizations at 75 and $100 \mathrm{~kg} \mathrm{~N} / \mathrm{ha}$ provided the soil with a large quantity of organic matter which, as it gradually degraded, provided the amount of nitrogen necessary for the plant's growth. Under the residual effect, despite the absence of fertilization, the organic matter from the remaining chicken manure in the soil for these two levels of fertilization continued to mineralize to provide sufficient nitrogen for optimal plant growth. The results obtained from the direct and residual effect of chicken manure fertilization levels on the evolution of the height and diameter of $B$. ruziziensis are in line with those obtained by Tendonkeng [11]. These Tendonkeng's results showed that the heights and diameters of B. ruziziensis plants increased with increasing levels of nitrogen fertilization. On the other hand, Zamil et al. [23] and Yerima et al. [13] have shown that chicken manure improves the availability of nitrogen, phosphorus and potassium, which promotes plant growth.

The biomasses of leaves and whole plants obtained under the residual effect of the fertilizer were higher than those obtained under the direct effect of the fertilizer. This could be explained by the interaction between fertilization and environmental factors such as precipitation, temperature and global radiation. The superiority of the biomasses of fertilized plants compared to those of control plot plants observed in this study would be related to the combined action of soil property improvement and nutrient mineralization initiated under the direct effect of the fertilizer. Indeed, studies conducted in the natural environment and in greenhouses (laboratory) by Mulaji [24] have shown that local resources such as organic waste, applied to poor, acidic tropical soils, can provide the nutrients needed for plant nutrition and growth and therefore increase crop yields. The biomasses of the plots fertilized at 75 and $100 \mathrm{~kg} \mathrm{~N} / \mathrm{ha}$ were higher than those of the plots fertilized at lower doses due to the direct and residual effect of the fertilizer. This is explained as demonstrated by Jama et al. [25] by the fact that the level of soil organic matter remains an important factor for maintaining soil fertility. Fertilizations at 75 and $100 \mathrm{~kg} \mathrm{~N} /$ ha provided the soil with more organic matter, which improved soil fertility and improved plant growth and yield. The increase in biomass with the level of nitrogen fertilization in the form of chicken manure observed in this study is in agreement with the observations of Pamo and Yonkeu [26] who observed in the Adamawa plateau (Cameroon) that nitrogen fertilization in the presence of phosphorus and potassium resulted in a significant increase in forage gramineae production from natural pastures.

\section{Conclusion}

This study was initiated to assess the direct and residual effects of increasing doses of chicken manure on the growth and biomass production of Brachiaria 
ruziziensis at the bolting. The contributions of fertilization in the form of chicken manure have had a positive effect on the growth and biomass production of B. ruziziensis. Thus, the heights, diameters and biomass of whole plants in the fertilized plots were higher than in the control plots. Data obtained on the growth of $B$. ruziziensis under the direct and residual effect of fertilizer indicated that mineralization of organic matter in chicken manure at doses of (75 and 100 $\mathrm{kg} \mathrm{N} / \mathrm{ha}$ ) was carried out in such a way as to ensure maximum plant growth, while fertilization at doses of ( 25 and $50 \mathrm{~kg} \mathrm{~N} / \mathrm{ha}$ ) could only provide the nutrients that could contribute to plant growth under the direct effect before it was exhausted. The level of $\mathrm{T}_{4}$ fertilization (corresponding to the dose of $100 \mathrm{~kg}$ $\mathrm{N} /$ ha) gave the best results. Referring to the result obtained, the level of T4 fertilization corresponding to $100 \mathrm{~kg} \mathrm{~N} /$ ha would be suitable for an optimal $B$. ruziziensis growth in order to avoid providing the soil with mineral fertilizer.

\section{Conflicts of Interest}

The authors declare no conflicts of interest regarding the publication of this paper.

\section{References}

[1] Tendonkeng, F., Boukila, B., Pamo, T.E., Mboko, A.V. and Tchoumboué, J. (2010) Effet de différents niveaux de fertilisation azotée sur le rendement et la composition chimique de Brachiaria ruziziensis à la montaison dans l'Ouest Cameroun. Livestock Research for Rural Development, 22, Article No. 19. http://www.lrrd.org/lrrd22/1/tend22019.htm

[2] Pamo, T.E., Tendonkeng, F., Kana, J.R., Boukila, B. and Nanda, A.S. (2006) Effect Calliandra calothyrsus and Leucaena leucocephala Supplementary Feeding Goat Production in Cameroon. Small Ruminant Research, 65, 31-37. https://doi.org/10.1016/j.smallrumres.2005.05.023

[3] Tendonkeng, F., Boukila, B., Pamo, T.E., Mboko, A.V. and Matumuini, N.E.F. (2011) Effet direct et résiduel de différents niveaux de fertilisation azotée sur la croissance et le rendement de Brachiaria ruziziensis à différents stades phénologiques. Tropicultura, 29, 197-204.

[4] Pamo, T.E., Boukila, B., Fonteh, F.A., Tendonkeng, F., Kana, J.R. and Nanda, A.S. (2007) Nutritive Values of Some Basic Grasses and Leguminous Tree Foliage of the Central Region of Africa. Animal Feed Science and Technology, 135, 273-282. https://doi.org/10.1016/j.anifeedsci.2006.07.001

[5] Pamo, T.E., Boukila, B., Meduke, C.N. and Tendonkeng, F. (2008) Effect of Nitrogen Fertilisation and Cutting Frequency on the Yield and Regrowth of Panicum maximum Jacq. in West Cameroon. 21 st International Grassland Congress, 8 th International Rangeland Congress, Hohhot, 29 June-5 July 2008, 354.

[6] JGRC (Japan Green Resources Corporation) (2001) Guide technique de l'élevage: Le développement pastoral efficace par la production d'herbe. In Documentation technique de la Japan Green Resources Corporation: Générer l'abondance dans le sahel par la lutte contre la désertification. Volume 7, $68 \mathrm{p}$.

[7] Daget, P. and Godron, M. (1995) Pastoralisme. Troupeaux, espaces et société. Hatier-AUPELF UREF, Paris, 510 p. 
[8] Obulbiga, M.F. and Kaboré-Zoungrana, C.Y. (2007) Influence de la fumure azotée et du rythme d'exploitation sur la production de matière sèche et la valeur alimentaire de Andropogon gayanus kunth au Burkina Faso. Tropicultura, 25, 161-167.

[9] Mboko, A.V., Tendonkeng, F., Matumuni, F.N.E., Zougou, G.T., Miégoué, E., Boukila, B. and Pamo, T.E. (2013) Effet comparé de deux légumineuses fertlisées au molybdène sur la croissance et le rendement de Brachiaria ruziziensis à différentes périodes de fauche dans l'Ouest Cameroun. International Journal of Biological and Chemical Sciences, 7, 2513-2525. https://doi.org/10.4314/ijbcs.v7i6.26

[10] Cook, B.G., Pengelly, B.C., Brown, S.D., Donnelly, J.L., Eagles, D.A., Franco, M.A., Hanson, J., Mullen, B.F., Partridge, I.J., Peters, M. and Schultze-Kraft, R. (2005) Tropical Forages: An Interactive Selection Tool. CIAT and ILRI, Brisbane.

[11] Tendonkeng, F. (2011) Effet de la fertilisation azotée, du stade phénologique et de l'année de fauche sur la croissance, le rendement et la valeur nutritive de Brachiaria ruziziensis Germain et Evrard. Thèse de Doctorat/PhD, Faculté d'Agronomie et des Sciences Agricoles, Université de Dschang, Cameroun, 186 p.

[12] Husson, O., Charpentier, H., Razanamparany, C., Moussa, N., Michellon, R., Naudin, K., Razafintsalama, H., Rakotoarinivo, C., Rakotondramanana and Seguy, L. (2008) Brachiaria sp., Manuel pratique du semis direct à Madagascar. Volume 3, Chapitre 4, 20 p. https://www.supagro.fr/ress-pepites/PlantesdeCouverture/res/brachiaria.pdf

[13] Yerima, B.P.K., Tiamgne, A.Y. and Van Ranst, E. (2014) Réponse de deux variétés de tournesol (Helianthus sp.) à la fertilisation à base de fiente de poule sur un Hapli-Humic Ferrasol du Yongka Western Highlands Research Garden Park (YWHRGP) Nkwen-Bamenda, Cameroun, Afrique centrale. Tropicultura, 32, 168-176.

[14] Suchel, J.B. (1989) Les privilèges climatiques du pays Bamiléké. Les Cahiers d'Outre-Mer, 165, 29-52. https://doi.org/10.3406/caoum.1989.3289

[15] Sanmarco, V. (1945) Les Bamilékè du district de Dschang. Exemple de l'influence du climat sur la vie indigène au Cameroun. Annales de Géographie. Bulletin de la Société de Géographie, 295, 223-224. https://doi.org/10.3406/geo.1945.12815

[16] Olivry, J.C. (1976) Régimes hydrologiques en pays Bamiléké (Cameroun). Cahier ORSTOM, Série Hydrologie, 13, 37-71.

[17] Pamo, T.E., Boukila, B., Fonteh, F.A., Tendonkeng, F. and Kana, J.R. (2005) Composition chimique et effet de la supplémentation avec Calliandra calothyrsus et Leucaena leucocephala sur la production laitière et la croissance des chevreaux nains de Guinée. Livestock Research for Rural Development, 17, Article No. 30. http://www.lrrd.org/lrrd17/3/tedo17030.htm

[18] Pauwels, J.M., Van Ranst, E., Verloo, M. and Mvondo Ze, A. (1992) Méthode d'analyse de sols et de plantes, gestion de stock de verrerie et de produits chimiques. Manuel de Laboratoire de Pédologie. Publications Agricoles, 28 p.

[19] Sys, C., Van Ranst, E., Debaveye, J. and Beernaert, F. (1991) Land evaluation part II. Methods for land evaluation. General Administration for Development Cooperation, Belgium.

[20] Mihoub, A. (2008) Effet de la fertilisation phosphatée sur la nutrition azotée et la productivité d'une culture de blé dur (Triticum durum I. Var. carioca) dans la région d'El-Goléa-Ghardaia. Mémoire d'ingénierie en sciences agronomique, Université de Kasdi-Merbah Ouarla, Algérie, 85 p. 
[21] Soltner, D. (2003) Les bases de la Production Végétale. Tome 2: Le sol et son amélioration. 18th Edition, Collection Sciences et Techniques Agricoles, $472 \mathrm{p}$.

[22] Steel, R.G. and Torrie, J.H. (1980) Principles and Procedures of Statistics. McGraw Hill Book C, New York, 633 p.

[23] Zamil, S.S., Quadir, F.Q., Chowdhury, M.A.H. and Al Wahid, A. (2004) Effect of Different Animal Manures on Yield Quality and Nutrient Uptake by Mustard cv. Agrani. BRAC University Journal, 1, 56-66.

[24] Mulaji, K.C. (2011) Utilisation des composts de bio déchet ménager pour l'amélioration de la fertilité des sols acides de la province de Kinshasa (République Démocratique du Congo). Thèse de doctorat, Université de Gembloux Agro bio tech, $220 \mathrm{p}$.

[25] Jama, B., Palm, C.A., Buresh, R.J., Niang, A.I., Gachengo, C. and Nziguheba, G. (2000) Tithonia as a Green Manure for Soil Fertility Improvement in Western Kenya. A Review Agroforestry Systems, 49, 201-221. https://doi.org/10.1023/A:1006339025728

[26] Pamo, T.E. and Yonkeu, S. (1993) Effect of Nitrogen Fertilizer in Combination with Potassium and Phosphorus on Rangeland Yield in Cameroon. Proceedings of the 17 th International Grassland Congress, Palmerston North, New Zealand, 8-21 February $1993,55-56$. 